\title{
Study Pemanfaatan Abu Bonggol Jagung Sebagai Bahan Substitusi Semen Untuk Beton Normal
}

\author{
Maria Prisila Hederanti Itu ${ }^{* 1}$, Herman Parung ${ }^{* 2}$, Junus Mara ${ }^{3}$ \\ *1 Mahasiswa Program Studi Teknik Sipil, Universitas Kristen Indonesia Paulus Makassar, \\ Indonesia mariaprisilahederanti1211@gmail.com \\ *2,3 Dosen Program Studi Teknik Sipil, Universitas Kristen Indonesia Paulus Makassar, Indonesia \\ ${ }^{2}$ hermanparung@gmail.com² dan mara.junus@gmail.com*3
}

Corresponding Author: mariaprisilahederanti1211@gmail.com

\begin{abstract}
Abstrak
Kemajuan teknologi dibidang konstruksi mengakibatkan kenaikan harga material seperti semen sehingga dilakukan penelitian untuk meningkatkan kualitas beton menggunakan bahan yang mudah didapat serta ramah lingkungan. Salah satunya adalah abu bonggol jagung yang diketahui mengandung Silika ( $\mathrm{SiO} 2$ ) 66,38\% yang dapat mengikat agregat pada campuran beton. Penelitian ini bertujuan mengetahui komposisi campuran beton dengan penggunaan abu bonggol jagung serta pengaruhnya terhadap karakteristik beton pada variasi $0 \%, 5 \%, 10 \%$, dan $15 \%$. Penelitian ini menggunakan metode mix deisgn yaitu American Concrete Institue (ACI) dengan mutu beton yang direncanakan f'c $30 \mathrm{MPa}$ dan menggunakan benda uji silinder ukuran $15 \times 30 \mathrm{~cm}$ serta balok ukuran $60 \times 15 \times 15 \mathrm{~cm}$. Dari hasil penelitian untuk variasi $0 \%, 5 \%, 10 \%$, dan $15 \%$ diperoleh nilai kuat tekan 32,633 MPa, 30,84 MPa, 20,749 MPa, dan 14,147 MPa, kuat tarik belah 2,806 MPa, 2,594 MPa, 2,075 MPa, dan 1,415 MPa, kuat lentur 3,979 MPa, 3,626 MPa, 2,518 $\mathrm{MPa}$, dan 1,712 MPa dan modulus elastisitas $22261,385 \mathrm{MPa}, 18509,487 \mathrm{MPa}, 14963,785 \mathrm{MPa}$, dan 11027,024 MPa. Hasil penelitian menunjukkan bahwa abu bonggol jagung tidak dapat meningkatkan karakteristik beton pada variasi diatas $4 \%$.
\end{abstract}

Kata kunci: Abu Bonggol Jagung, Kuat Tekan, Kuat Tarik Belah, Kuat Lentur, dan Modulus Elastisitas

\begin{abstract}
Advances in construction fields resulting in increase in material prices such as cement so that study is carried out to improve concrete quality using materials that are easy to obtain as well as environmentally friendly. One of them is corn cob ash that is known to contain successive that can tie the aggregate of the concrete mixture. This study aimed to know the composition of concrete mixture with the use of corn cob ash and the effect on concrete characteristics in the variety 0\%, $5 \%, 10 \%$, and $15 \%$. This study uses method mix design is American Concrete Institue (ACI) with planned concrete quality f'c $30 \mathrm{MPa}$ and uses a cylinder dimensional $15 \times 30 \mathrm{~cm}$ and beam dimension $60 \times 15 \times 15 \mathrm{~cm}$. The result showed that corn cob ash can't increase concrete characteristics in the variety above $4 \%$.
\end{abstract}

Keywords: Corn Cob Ash, Compressive Strength, Tensile Strength, Flexible Strength, and Modulus of Elasticity 


\section{PENDAHULUAN}

Kemajuan teknologi pada bidang konstruksi semakin hari semakin meningkat, hal ini dapat dilihat dengan banyaknya pembangunan-pembangunan yang dilakukan demi meningkatkan perekonomian. Dengan banyaknya perkembangan konstruksi maka penggunaan material penyusunnya juga semakin meningkat salah satunya adalah penggunaan beton yang merupakan salah satu material penting dan paling banyak digunakan dalam suatu konstruksi.

Namun, seiring berjalannya waktu nilai ekonomis semakin menurun salah satunya ditandai dengan meningkatnya harga material bangunan khususnya material semen yang merupakan salah satu bahan utama dalam campuran beton. Banyak penelitian yang dilakukan pada beton sebagai upaya untuk meningkatkan kualitas beton dengan memanfaatkan bahan yang mudah didapat, ramah lingkungan dan harga yang ekonomis dengan cara mencari bahan lain yang dapat digunakan sebagai bahan aditif atau bahan pengganti semen pada campuran beton. Hal ini dilakukan untuk memberikan solusi yang baik dalam mengurangi atau mengganti penggunaan semen pada campuran beton.

Hal inilah yang mendorong pemanfaatan abu bonggol jagung sebagai bahan substitusi semen. Pada industri pakan ayam, bonggol jagung yang sudah tidak dibutuhkan dibuang disekitar pabrik dan menjadi limbah yang dapat mencemari lingkungan dan hanya digunakan untuk pakan ternak sapi. Bonggol jagung yang sudah tidak digunakan ternyata dapat digunakan sebagai bahan substitusi semen karena bonggol jagung yang dibakar dan menjadi abu mengandung senyawa $\mathrm{SiO}_{2}$ yang memiliki kerekatan yang sama seperti semen.

Tabel 1. Kandungan Abu Bonggol Jagung [13]

\begin{tabular}{cc}
\hline Senyawa Kimia & Presentase Komposisi (\%) \\
\hline $\mathrm{SiO}_{2}$ & 66,38 \\
\hline $\mathrm{Al}_{2} \mathrm{O}_{3}$ & 7,48 \\
\hline $\mathrm{Fe}_{2} \mathrm{O}_{3}$ & 4,44 \\
\hline $\mathrm{CaO}$ & 11,57 \\
\hline $\mathrm{SO}_{3}$ & 1,07 \\
\hline $\mathrm{Na}_{2} \mathrm{O}$ & 0,41 \\
\hline $\mathrm{K}_{2} \mathrm{O}$ & 4,92 \\
\hline
\end{tabular}

Penggunaan abu bonggol jagung sebagai bahan substitusi semen agar mengurangi pencemaran lingkungan serta mengurangi penggunaan semen pada campuran beton.

Penelitian yang membahas terkait abu bonggol jagung antara lain Pengaruh Penambahan Abu Bonggol Jagung Terhadap Kuat Tekan Beton K-200. Dengan presentase penggunaan abu bonggol jagung yaitu $0 \%, 4 \%, 8 \%$, dan $12 \%$ dari berat semen. Dari penelitian ini diperoleh hasil nilai substitusi abu bonggol jagung yang optimal adalah pada varian $4 \%$ yaitu 33,04 MPa, 336,80 kg/cm ${ }^{2}$.[1]

Kajian Kuat Tekan Beton Akibat Substitusi Parsial Abu Bonggol Jagung Terhadap Semen. Penelitian ini menggunakan presentase penggunaan abu bonggol jagung yaitu $0 \%, 2,5 \%, 5 \%, 7,5 \%, 10 \%, 12,5 \%, 15 \%$, dan $17,5 \%$ terhadap berat awal semen. Hasil yang diperoleh yaitu beton dengan $2,5 \%$ dan $5 \%$ abu bonggol jagung mengalami peningkatan kuat tekan sedangkan beton abu bonggol jagung dengan kadar 7,5\% - 17,5\% mengalami penurunan kekuatan. Nilai kuat tekan optimal yang dicapai pada saat kadar 5\%.[2]

Pengaruh Penambahan Variasi Abu Janggel Jagung dengan Serat Bambu Terhadap Uji Kuat Tarik Belah Beton. Penelitian ini menggunakan abu janggel jagung sebagai substitusi parsial dari semen dan serat 
bambu ukuran panjang $5 \mathrm{~cm}$ dan diameter $1 \mathrm{~cm}$. Diperolah hasil benda uji beton dengan nilai kuat tarik yang melebihi beton normal.[3]

Kajian Penambahan Abu Bonggol Jagung Yang Bervariasi dan Bahan Tambah Superplasticizer Terhadap Sifat Fisik dan Mekanik Beton Memadat Sendiri (Self-Compacting Concrete). Pada penelitian ini, variasi presentase abu bonggol jagung adalah $0 \%, 4 \%, 8 \%$, dan $12 \%$. Diperoleh hasil penelitian bahwa nilai kuat tekan tertinggi umur 28 hari didapatkan pada abu bonggol jagung variasi $4 \%$ sebesar 36,25 MPa [4]

Pemanfaatan Abu Bonggol Jagung Sebagai Bahan Tambah Semen Pada Pembuatan Bata Ringan Jenis CLC. Pada penelitian ini, variasi presentase abu bonggol jagung adalah $0 \%, 4 \%, 6 \%, 8 \%$, dan $10 \%$. Diperoleh hasil penelitian bahwa nilai kuat tekan optimum berada pada variasi $6 \%$ dengan syarat minimum 3,6 N/mm². [5]

Pengaruh Penambahan Limbah Tongkol Jagung Untuk Pembuatan Batu Bata Ringan. Pada penelitian ini menggunakan variasi abu tongkol jagung $0 \%, 2,5 \%, 5 \%, 7,5 \%, 10 \%$, dan 12,5\% dengan menggunakan ayakan $>60$ mesh. Hasil penelitian menunjukkan bahwa kualitas batu bata dengan ukuran butir tongkol jagung >60 mesh dengan variasi hingga 12,5\% masih memenuhi kuat tekan kelas 50. [6]

Pengaruh Penambahan Abu Tongkol Jagung Terhadap Kuat Tekan Beton Dengan Menggunakan Agregat Kasar Palu dan Agregat Halus Pasir Tenggarong. Pengujian kuat tekan menggunakan 4 variasi kadar abu tongkol jagung mulai dari 2,5\%, 5\%, 7,5\%, dan 10\%. Berdasarkan analisis data dari hasil pengujian kuat tekan, diperoleh peningkatan kuat tekan maksimum yaitu 23,714 MPa pada kadar optimum 5,3\%. [7]

Pengaruh Penggunaan Abu Tongkol Jagung Sebagai Bahan Tambah Semen Terhadap Karakteristik Paving Block. Penelitian ini menggunakan variasi abu tongkol jagung sebesar 0\%, 2,5\%, 5\%, 7,5\%, dan $10 \%$. Dari hasil penelitian diperoleh nilai kuat tekan maksimum terjadi pada proporsi penambahan 5,35\% abu tongkol jagung yaitu sebesar 1,13 MPa.[8]

\section{METODOLOGI}

Lokasi pengambilan abu bonggol jagung berada pada produksi pakan ayam yang terletak di Kota Maros, Sulawesi Selatan, serta agregat halus dan agregat kasar diperoleh dari Sungai Jeneberang, Kabupaten Gowa, Sulawesi Selatan.

\section{Karakteristik Agregat}

Bahan yang paling utama dalam pembuatan beton adalah agregat. Dengan menggunakan agregat pada beton, maka agregat mampu memberikan kekerasan yang mampu untuk menahan beban beton.

\section{a. Agregat Halus}

Agregat halus yang digunakan pada beton dapat berupa pasir alam sebagai hasil desintegrasi alami dari batuan - batuan atau berupa pasir buatan yang dihasilkan oleh alat pemecah batu.

Agregat halus yang akan digunakan dalam campuran beton beton harus dalam keadaam bersih dan tidak terdapat lumpur diatas $6 \%$.

\section{b. Agregat Kasar}

Agergat kasar (kerikil) merupakan hasil alamiah batuan berupa batu pecah yang diproses pada sebuah industri dengan ukuran 4,75-1,50 mm. Agregat ini harus bertekstur keras dan tidak berpori serta dalam keadaan bersih (tidak berlumpur) ketika akan digunakan.

\section{c. Bahan Pengikat (Filler)}

Filler merupakan bahan atau fraksi dari agregat halus yang lolos saringan no.200 yang biasanya digunakan abu batu, abu kapur, semen, ataupun bahan lain. 


\section{Karakteristik Beton}

\section{a. Kuat Tekan Beton (SNI 1974:2011)}

Kuat tekan beton merupakan perbandingan antara besar kekuatan beban terhadap luasnya yang diakibatkan oleh tekanan dari sebuah mesin tekan.

Perhitungan kuat tekan beton digunaan persamaan di bawah ini [9]:

$$
\mathrm{f}^{\prime} \mathrm{c}=\frac{\mathrm{P}}{\mathrm{A}}
$$

Keterangan :

$\mathrm{f}^{\prime} \mathrm{c} \quad=$ Kuat tekan beton $(\mathrm{MPa})$

$\mathrm{P} \quad=$ Beban maksimum $(\mathrm{N})$

A = Luas penampang benda uji $\left(\mathrm{mm}^{2}\right)$

Proses kerja dari uji kuat tekan pada beton dapat dilihat pada gambar berikut :

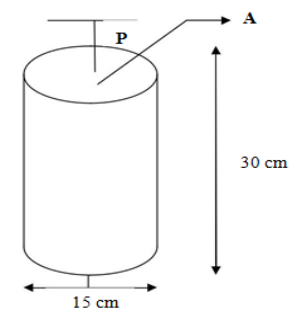

Gambar 1. Uji kuat tekan

\section{b. Kuat Tarik Belah (SNI 2491:2014)}

Kuat tarik belah merupakan uji beton yang dilakukan terhadap silinder beton yang ditekan dari arah memanjang.

Untuk menentukan besarnya nilai kuat tarik yang diperoleh, maka dapat digunakan persamaan di bawah ini [10] :

$$
\mathrm{ft} \quad=\frac{2 \mathrm{P}}{\pi \mathrm{Ld}}
$$

Keterangan :

$\mathrm{ft} \quad=$ Kuat tarik belah beton (MPa)

$\mathrm{P} \quad=$ Besarnya beban $(\mathrm{N})$

$\mathrm{L} \quad=$ Panjang benda uji $(\mathrm{mm})$

$\mathrm{d} \quad=$ Diameter benda uji $(\mathrm{mm})$

Mekanisme uji kuat tarik belah beton, seperti pada gambar :
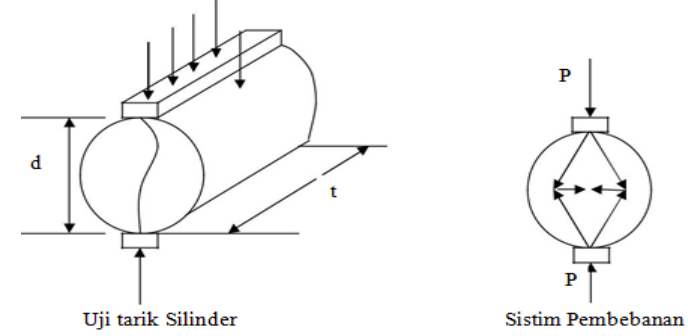


\section{c. Kuat lentur beton ( Berdasarkan SNI 4431-2011)}

Lentur pada balok merupakan akibat dari adanya regangan yang timbul karena adanya beban luar (E.G. Nawy 1998) [11]. Balok dapat mengalami deformasi ketika beban dan regangan dari balok bertambah yang mengakibatkan terjadinya retak di sepanjang balok. Keruntuhan pada suatu struktur diakibatkan karena terjadi penambahan beban sehingga ketika beban yang dihasilkan telah mencapai maksimumnya maka balok tersebut akan luntur akibat lentur.

Nilai dari Kuat lentur beton dapat diperoleh dari Persamaan berikut, yang disesuaikan dengan pengujiannya [12].

$$
f_{r}=\frac{P \times L}{b \times h^{2}}
$$

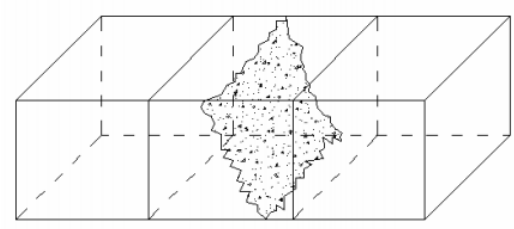

Gambar 3. Mekanisme pengujian kuat lentur dengan keruntuhan di tengah bentang Persamaan 3 tersebut dipakai ketika balok runtuh ditengah bentang.

Jika balok runtuh ada tengah bentang bagian luar, maka dapat menggunakan rumus di bawah ini [12]:

$$
f_{r}=\frac{P \times a}{b \times h^{2}}
$$

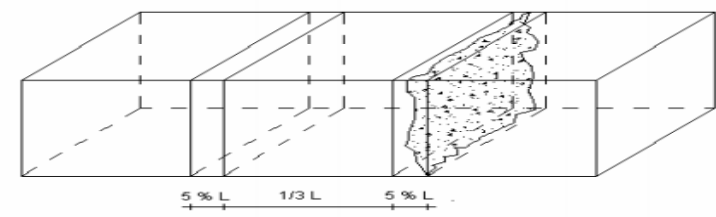

Gambar 4. Mekanisme pengujian lentur dengan keruntuhan di luar tengah bentang

Sedangkan apabila balok mengalami runtuh pada 1/3 tengah bentang maka, dapat menggunakan mekanisme berikut ini :

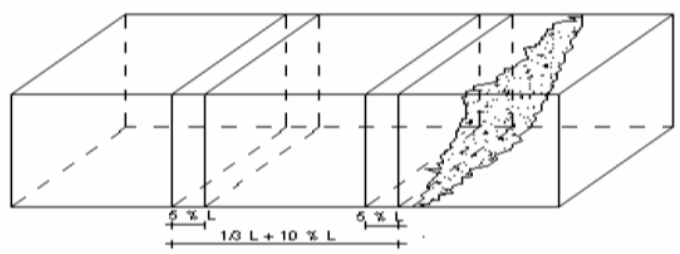

Gambar 5. Patah diluar $1 / 3$ bentang tengah dan garis patah pada $>5 \%$ dari bentang

Dimana :

$\mathrm{f}_{\mathrm{r}} \quad=$ Kuat lentur benda uji (Mpa)

$\mathrm{L} \quad=$ Jarak bentang antara dua garis perletakan

$\mathrm{b} \quad=$ Lebar penampang lintang patah arah horizontal $(\mathrm{cm})$ 
$P \quad=$ Beban tertinggi yang terbaca pada mesin uji (Pembacaan dalam ton sampai 3 angka di belakang koma)

$\mathrm{h} \quad=$ Lebar penampang lintang patah arah vertikal $(\mathrm{cm})$

$a \quad=$ Jarak rata-rata antara penampang lintang patah dan tumpuan luar yang terdekat, diukur pada 4 tempat pada sudut dari bentang $(\mathrm{cm})$

Besarnya tegangan yang terjadi pada uji kuat lentur terdapat pada bawah balok yang tidak disertai tulangan yang dapat berpengaruh terhadap nilai kuat tariknya.

\section{d. Modulus Elastisitas Beton}

Modulus elastisitas merupakan pengujian untuk menentukan besarnya daya tahan beban atas deformasinya yang ditentukan pada hasil perubahan tegangan terhadap regangan pada batas elastis.

Nilai dari modulus elastisitas dapat ditentukan menggunakan persamaan berikut [9]:

$$
\mathrm{Ec}=\frac{\mathrm{S} 2-\mathrm{S} 1}{\varepsilon 2-0,00005}
$$

Dengan :

$\mathrm{Ec}=$ Modulus elastisitas beton $(\mathrm{MPa})$

$\mathrm{S}_{2}=$ besar tegangan saat $40 \%$ beban batas (MPa)

$\mathrm{S}_{1}=$ besar tegangan saat regangan $0,00005(\mathrm{MPa})$

$\varepsilon 2=$ regangan saat $40 \%$ beban batas 60

\section{ANALISA DAN PEMBAHASAN}

\section{Karakteristik Agregat}

\section{Agregat Halus}

Tabel 2. Spesifikasi Karakteristik Agregat Halus

\begin{tabular}{cccc}
\hline No. & Karakteristik agregat halus & $\begin{array}{c}\text { Batas } \\
\text { interval }\end{array}$ & Pedoman \\
\hline 1 & Kadar Organik Warna & $<$ No.3 & SNI 2816-2014 \\
\hline 2 & Kadar air, \% & $3,0-5,0$ & SNI 03-1971-2011 \\
\hline 3 & Berat Volume Padat, kg/ltr & $1,40-1,90$ & SNI 03-4804-1998 \\
\hline 4 & Berat Volume Gembur, kg/ltr & $0,20-2,00$ & SNI 03-4804-1998 \\
\hline 5 & Penyerapan, $\%$ & $0,20-2,00$ & SNI 1970-2008 \\
\hline 6 & Berat Jenis (SSD) & $1,6-3,2$ & SNI 1970-2008 \\
\hline 7 & Modulus Kehalusan & $2,20-3,10$ & SNI 03-1968-1990 \\
\hline
\end{tabular}

Tabel 3. Hasil Pemeriksaan Agregat Halus

\begin{tabular}{ccccc}
\hline No. & Karakteristik Agregat Halus & Hasil & Interval SNI & Keterangan \\
\hline 1 & Kadar Lumpur, $\%$ & 2,50 & $0,2-6$ & Memenuhi \\
\hline 2 & Kadar Organik, Warna & $<3$ & $<$ No. 3 & Memenuhi \\
\hline 3 & Kadar Air, $\%$ & 3,521 & $3,0-5,0$ & Memenuhi \\
\hline 4 & Berat Volume Padat, kg/ltr & 1,433 & $1,40-1,90$ & Memenuhi \\
\hline 5 & Berat Volume Gembur, kg/ltr & 1,418 & $1,40-1,90$ & Memenuhi \\
\hline 6 & Penyerapan, $\%$ & 1,113 & $0,20-2,00$ & Memenuhi \\
\hline 7 & Berat Jenis, SSD & 2,612 & $1,6-3,2$ & Memenuhi \\
\hline 8 & Modulus Kehalusan & 2,562 & $2,20-3,10$ & Memenuhi \\
\hline
\end{tabular}


Volume 3 Issue 4, Desember 2021

\section{Agregat Kasar}

Tabel 4. Spesifikasi Karakteristik Agregat Kasar

\begin{tabular}{cccc}
\hline No. & Karakteristik Agregat Kasar & Interval Batas & Pedoman \\
\hline 1 & Kadar air, $\%$ & $0,5-2,0$ & SNI 03-1971-2011 \\
\hline 2 & Kadar Lumpur, \% & $0,2-1,0$ & SNI 03-4142-1996 \\
\hline 3 & Berat Volume Padat, kg/ltr & $1,40-1,90$ & SNI 03-4804-1998 \\
\hline 4 & Berat Volume Gembur, kg/ltr & $1,40-1,90$ & SNI 03-4804-1998 \\
\hline 5 & Penyerapan, \% & $0,2-2,00$ & SNI 1969-2008 \\
\hline 6. & Berat Jenis (SSD) & $1,60-3,20$ & SNI 1969-2008 \\
\hline
\end{tabular}

Tabel 5. Hasil Pemeriksaan Agregat Kasar

\begin{tabular}{ccccc}
\hline No. & Karakteristik Agregat Kasar & Hasil & Interval SNI & Keterangan \\
\hline 1 & Kadar Lumpur, \% & 0,704 & $0,2-1,00$ & Memenuhi \\
2 & Kadar Air, \% & 0,858 & $0,50-2,00$ & Memenuhi \\
3 & Berat Volume Padat, kg/ltr & 1571,131 & $1,4-1,9$ & Memenuhi \\
4 & Berat Volume Gembur, kg/ltr & 1501,488 & $1,4-1,9$ & Memenuhi \\
5 & Penyerapan, \% & 1,813 & $0,20-2,00$ & Memenuhi \\
6 & Berat Jenis, SSD & 2,621 & $1,60-3,20$ & Memenuhi \\
\hline
\end{tabular}

Bahan Pengikat (Filler)

Tabel 6. Hasil Pemeriksaan Bahan Pengikat

\begin{tabular}{ccccc}
\hline No. & Karakteristik Agregat Halus & Hasil & Interval SNI & Keterangan \\
\hline 1 & Berat Jenis Semen & 3,16 & $3,0-3,20$ & Memenuhi \\
\hline
\end{tabular}

\section{Karakteristik Beton}

\section{Hasil Pengujian Kuat tekan beton}

Pengujian kuat tekan beton dilakukan berdasarkan SNI 1974-2011 dan dilakukan pada benda uji yang berumur 7, 14, dan 28 hari. Pengujian ini dilakukan pada Compression Testing Machine. Pengujian ini bertujuan untuk mengetahui kekuatan beton dalam menerima beban tekan dalam satuan KN. Berikut hasil perhitungan dari hasil pengujian kuat tekan beton berdasarkan variasi presentase $0 \%, 5 \%, 10 \%$, dan $15 \%$ dari jumlah abu bonggol jagung.

Tabel 7. Hasil Pengujian Kuat Tekan Beton

\begin{tabular}{|c|c|c|c|c|}
\hline $\begin{array}{c}\text { Variasi Abu } \\
\text { Bonggol Jagung }\end{array}$ & $\begin{array}{l}\text { Umur } \\
\text { (Hari) }\end{array}$ & $\begin{array}{c}\text { Beban Maksimum } \\
(\mathrm{KN})\end{array}$ & $\begin{array}{c}\text { Kuat Tekan Beton } \\
\text { Aktual (MPa) }\end{array}$ & $\begin{array}{c}\text { Kuat Tekan Beton Aktual } \\
\text { Rata-Rata (MPa) }\end{array}$ \\
\hline \multirow{9}{*}{ ABJ $0 \%$} & \multirow{3}{*}{7} & 355 & 20,089 & \multirow{3}{*}{20,183} \\
\hline & & 345 & 19,523 & \\
\hline & & 370 & 20,938 & \\
\hline & \multirow{3}{*}{14} & 495 & 28,011 & \multirow{3}{*}{28,294} \\
\hline & & 500 & 28,294 & \\
\hline & & 505 & 28,577 & \\
\hline & \multirow{3}{*}{28} & 585 & 33,104 & \multirow{3}{*}{32,633} \\
\hline & & 575 & 32,538 & \\
\hline & & 570 & 32,255 & \\
\hline ABJ 5\% & 7 & 355 & 20,089 & 19,334 \\
\hline
\end{tabular}




\begin{tabular}{|c|c|c|c|c|}
\hline & & 335 & 18,957 & \\
\hline & & 335 & 18,957 & \\
\hline & \multirow{3}{*}{14} & 470 & 26,597 & \multirow{3}{*}{26,691} \\
\hline & & 480 & 27,162 & \\
\hline & & 465 & 26,314 & \\
\hline & \multirow{3}{*}{28} & 550 & 31,124 & \multirow{3}{*}{30,841} \\
\hline & & 545 & 30,841 & \\
\hline & & 540 & 30,558 & \\
\hline \multirow{9}{*}{ ABJ $10 \%$} & \multirow{3}{*}{7} & 220 & 12,449 & \multirow{3}{*}{12,921} \\
\hline & & 235 & 13,298 & \\
\hline & & 230 & 13,015 & \\
\hline & \multirow{3}{*}{14} & 290 & 16,411 & \multirow{3}{*}{17,731} \\
\hline & & 320 & 18,108 & \\
\hline & & 330 & 18,674 & \\
\hline & \multirow{3}{*}{28} & 365 & 20,655 & \multirow{3}{*}{20,749} \\
\hline & & 365 & 20,655 & \\
\hline & & 370 & 20,938 & \\
\hline \multirow{9}{*}{ ABJ $15 \%$} & \multirow{3}{*}{7} & 150 & 8,488 & \multirow{3}{*}{8,394} \\
\hline & & 155 & 8,771 & \\
\hline & & 140 & 7,922 & \\
\hline & \multirow{3}{*}{14} & 205 & 11,601 & \multirow{3}{*}{12,261} \\
\hline & & 215 & 12,167 & \\
\hline & & 230 & 13,015 & \\
\hline & \multirow{3}{*}{28} & 255 & 14,430 & \multirow{3}{*}{14,147} \\
\hline & & 245 & 13,864 & \\
\hline & & 250 & 14,147 & \\
\hline
\end{tabular}

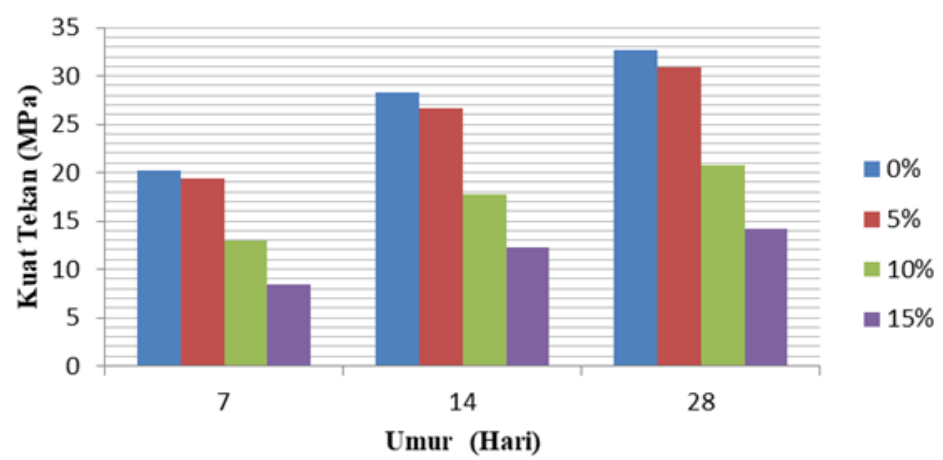

Gambar 6. Hasil Pengujian kuat tekan beton terhadap umur beton

Kuat tekan beton dari variasi presentase abu bonggol jagung semakin meningkat seiring bertambahnya umur beton.

\section{Hasil Pengujian Kuat Tarik Belah Beton}

Pengujian ini dilakukan agar dapat diketahui besar gaya tarik maksimum beton. Pengujian kuat tarik belah beton dilakukan pada saat benda uji berumur 28 hari.

Tabel 8. Hasil Pengujian Kuat Tarik Belah Beton

\begin{tabular}{cccc}
\hline $\begin{array}{c}\text { Variasi Abu } \\
\text { Bonggol Jagung }\end{array}$ & $\begin{array}{c}\text { Beban Maksimum } \\
(\mathrm{KN})\end{array}$ & $\begin{array}{c}\text { Kuat Tarik Belah } \\
\text { Aktual }(\mathrm{MPa})\end{array}$ & $\begin{array}{c}\text { Kuat Tarik Belah Aktual } \\
\text { Rata-Rata (MPa) }\end{array}$ \\
\hline \multirow{2}{*}{$0 \%$} & 200 & 2,829 & 2,806 \\
\cline { 2 - 3 } & 205 & 2,900 & 2 \\
\hline
\end{tabular}




\begin{tabular}{llll}
\hline & 190 & 2,688 & \\
\hline \multirow{3}{*}{$5 \%$} & 190 & 2,688 & \multirow{2}{*}{2,594} \\
\cline { 2 - 3 } & 185 & 2,617 & \\
\cline { 2 - 3 } $10 \%$ & 175 & 2,476 & 2,075 \\
& 140 & 1,981 & \\
\cline { 2 - 3 } & 155 & 2,193 & \multirow{2}{*}{1,415} \\
\hline \multirow{3}{*}{$15 \%$} & 145 & 2,051 & \\
\cline { 2 - 4 } & 105 & 1,485 & 1,415 \\
\hline
\end{tabular}

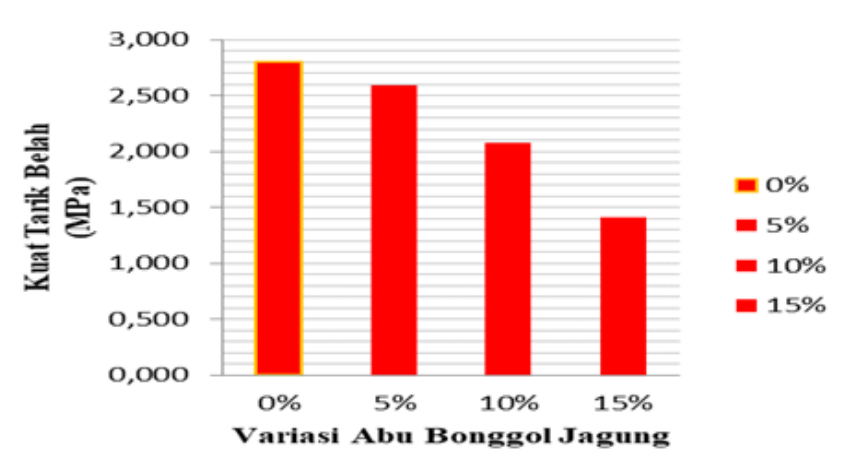

Gambar 8. Hasil Pengujian kuat tarik belah beton terhadap variasi abu bonggol jagung

Kuat tarik belah beton terbesar pada substitusi $0 \%$ yaitu 2,806 MPa. Namun, bila dilihat dari hasil perhitungan dapat disimpulkan bahwa semakin tinggi presentase variasi abu bonggol jagung maka nilai kuat tarik belah semakin menurun.

\section{Hasil Pengujian Kuat lentur beton}

Pengujian ini dilakukan pada balok ukuran $60 \times 15 \times 15 \mathrm{~cm}$. Benda uji pada kuat lentur diletakkan pada alat uji lentur dengan dua titik pembebanan.

Tabel 9. Hasil Pengujian Kuat Lentur Beton

\begin{tabular}{|c|c|c|c|}
\hline $\begin{array}{l}\text { Variasi Bonggol } \\
\text { Jagung }\end{array}$ & $\begin{array}{l}\text { Beban Maksimum } \\
(\mathrm{P})\end{array}$ & $\begin{array}{l}\text { Kuat Lentur } \\
\text { (MPa) }\end{array}$ & $\begin{array}{c}\text { Rata-rata } \\
\text { Kuat Lentur } \\
(\mathrm{MPa})\end{array}$ \\
\hline \multirow{2}{*}{$0 \%$} & 27459 & 4,231 & \multirow{2}{*}{3,979} \\
\hline & 25497 & 3,928 & \\
\hline \multirow{3}{*}{$5 \%$} & 23536 & 3,626 & \multirow{3}{*}{3,626} \\
\hline & 24517 & 3,777 & \\
\hline & 22555 & 3,475 & \\
\hline \multirow{3}{*}{$10 \%$} & 16671 & 2,569 & \multirow{3}{*}{2,518} \\
\hline & 14710 & 2,266 & \\
\hline & 17652 & 2,720 & \\
\hline \multirow{3}{*}{$15 \%$} & 11768 & 1,813 & \multirow{3}{*}{1,712} \\
\hline & 10787 & 1,662 & \\
\hline & 10787 & 1,662 & \\
\hline
\end{tabular}




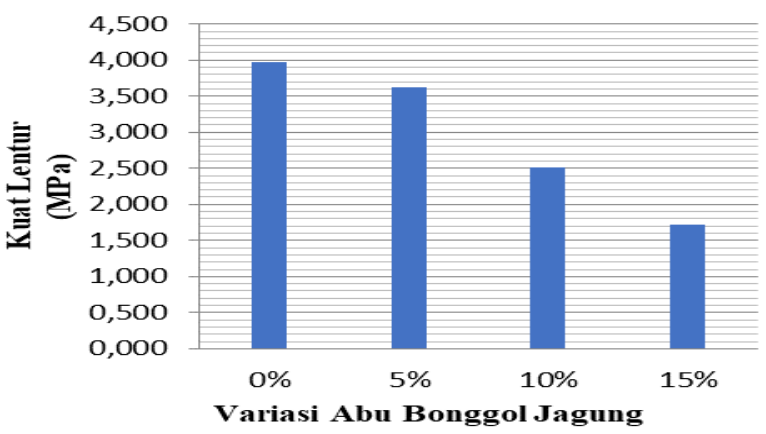

Gambar 9. Hasil Pengujian kuat lentur beton terhadap variasi abu bonggol jagung

Hubungan antara variasi abu bonggol jagung terhadap kuat lenturnya beton semakin menurun seiring dengan bertambahnya variasi abu bonggol jagung.

\section{Hasil Pengujian Modulus Elastisitas Beton}

Perhitungan modulus elastisitas beton bertujuan untuk mengetahui besarnya beban yang dapat dipikul tanpa merusak beton itu sendiri. Pengujian modulus elastisitas beton dilakukan pada umur beton 28 hari. Pengujian modulus elastisitas dilakukan bersamaan dengan pengujian kuat tekan beton.

Tabel 10. Hasil Pengujian Modulus Elastisitas Beton

\begin{tabular}{|c|c|c|c|c|}
\hline $\begin{array}{l}\text { Variasi Bonggol } \\
\text { Jagung }\end{array}$ & $\begin{array}{c}\text { Modulus } \\
\text { Elastisitas (MPa) }\end{array}$ & $\begin{array}{l}\text { Rata-Rata Modulus } \\
\text { Elastisitas (MPa) }\end{array}$ & $\begin{array}{l}\text { Modulus Elastisitas } \\
\text { Teoritis }\left(4700 \sqrt{f^{\prime} c}\right)\end{array}$ & $\begin{array}{l}\text { Modulus Elastisitas } \\
\text { Teoritis }\left(4700 \sqrt{f^{\prime} c}\right)\end{array}$ \\
\hline \multirow{3}{*}{$0 \%$} & 22064,161 & \multirow{3}{*}{22261,385} & 27042,049 & \multirow{3}{*}{26848,359} \\
\hline & 23110,397 & & 26809,924 & \\
\hline & 21609,596 & & 26693,104 & \\
\hline \multirow{3}{*}{$5 \%$} & 17591,355 & \multirow{3}{*}{18509,487} & 26220,623 & \multirow{3}{*}{26100,983} \\
\hline & 19533,517 & & 26101,166 & \\
\hline & 18403,590 & & 25981,160 & \\
\hline \multirow{3}{*}{$10 \%$} & 16939,719 & \multirow{3}{*}{14963,785} & 21360,337 & \multirow{3}{*}{21408,939} \\
\hline & 14756,712 & & 21360,337 & \\
\hline & 13194,924 & & 21506,143 & \\
\hline \multirow{3}{*}{$15 \%$} & 10517,528 & \multirow{3}{*}{11027,024} & 17853,845 & \multirow{3}{*}{17677,351} \\
\hline & 10625,211 & & 17500,268 & \\
\hline & 11938,332 & & 17677,940 & \\
\hline
\end{tabular}
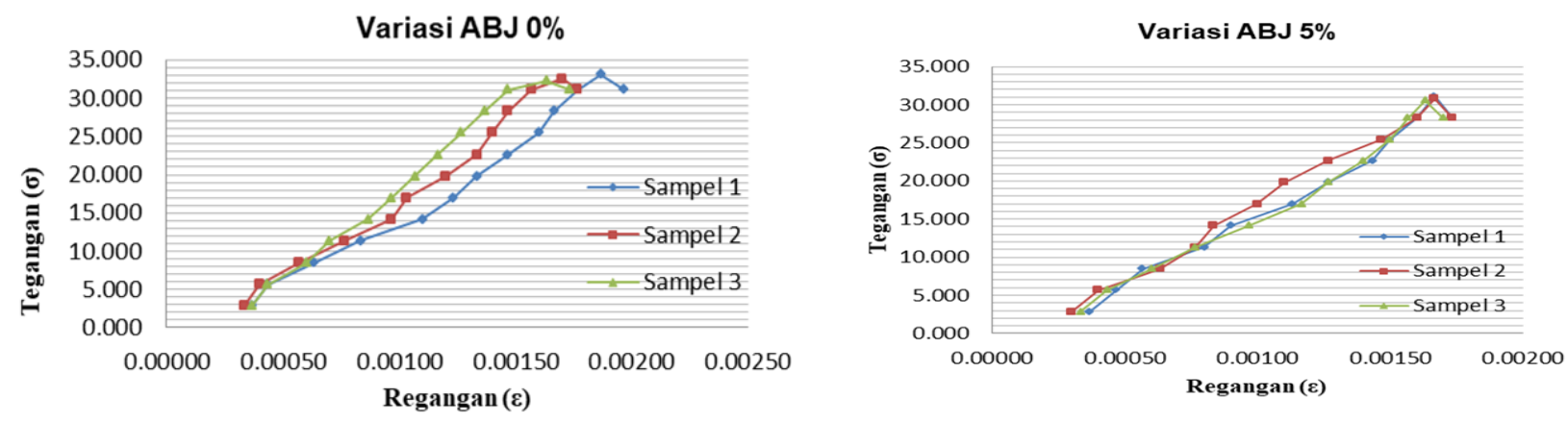

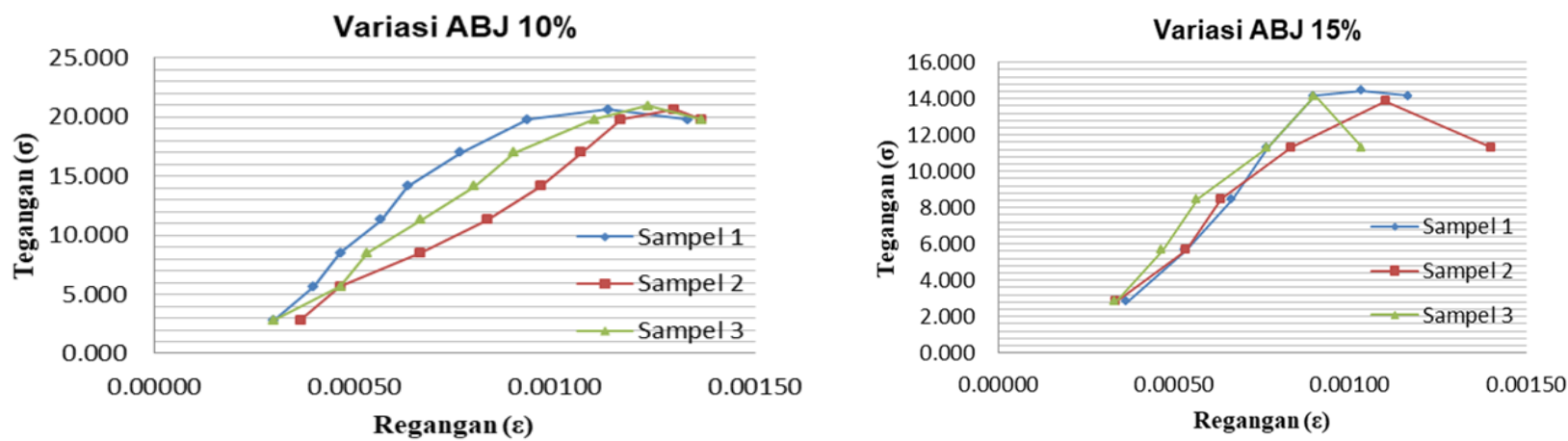

Gambar 10. Hubungan antara Tegangan $(\sigma)$ dengan Regangan $(\varepsilon)$

Hubungan antara tegangan dan regangan pada variasi $0 \%$ terjadi tegangan maksimum sebesar 33,104 MPa dengan nilai regangan 0,00187 dan terdapat pada sampel 1, pada variasi $5 \%$ terjadi tegangan maksimum sebesar 31,124 MPa dengan nilai regangan 0,00167 dan terdapat pada sampel 1, pada variasi $10 \%$ terjadi tegangan maksimum sebesar 20,938 $\mathrm{MPa}$ dengan nilai regangan 0,00123 dan terdapat pada sampel 3, dan pada variasi $15 \%$ terjadi tegangan maksimum sebesar 14,430 $\mathrm{MPa}$ dengan nilai regangan 0,00103 dan terdapat pada sampel 1 .

\section{KESIMPULAN}

Komposisi campuran beton menggunakan abu bonggol jagung sebagai bahan substitusi semen diperoleh nilai perbandingan semen, pasir, dan kerikil sebesar $1: 1,387: 2,373$ dengan berat abu bonggol jagung sesuai presentase variasinya.

Penggunaan abu bonggol jagung sebagai bahan substitusi semen diketahui bahwa abu bonggol jagung tidak dapat meningkatkan nilai karakteristik beton pada variasi $5 \%, 10 \%$ dan $15 \%$. Pada penggunaan abu bonggol jagung, nilai optimal dapat diperoleh hanya pada variasi dibawah 5\%.

\section{DAFTAR PUSTAKA}

[1] R. Hepiyanto, M. A. Firdaus, 2019. "Pengaruh Penambahan Abu Bonggol Jagung Terhadap Kuat Tekan Beton K-200”. Jurnal Teknik. Vol. 3 No.2. ISSN: 2579-4620. Universitas Islam Lamongan, Jawa Timur.

[2] L. N. B. Berutu, 2020. "Kajian Kuat Tekan Beton Akibat Substitusi Parsial Abu Bonggol Jagung Terhadap Semen”. Jurnal Teknik Sipil. Universitas Sumatera Utara.

[3] K. A. Almachzunny,dkk. 2020. "Pengaruh Penambahan Variasi Abu Janggel Jagung Dengan Serat Bambu Terhadap Uji Kuat Tarik Belah Beton”. Jurnal Teknik. Vol 8 No.2. ISSN: 2337-7720. Universitas Islam Malang.

[4] N.Fakhrunisa,dkk.2018. "Kajian Penambahan Abu Bonggol Jagung Yang Bervariasi dan Bahan Tambah Superplasticizer Terhadap Sifat Fisik dan Mekanik Beton Memadat Sendiri (Self-Compacting Concrete)". Jurnal Bangunan. Vol. 23 No.2. ISSN: 0852-2480. Universitar Negeri Malang.

[5] M. A. Nugraha. 2021. "Pemanfaatan Abu Bonggol Jagung Sebagai Bahan Tambah Semen Pada Pembuatan Bata Ringan Jenis CLC”. Jurnal Teknik Sipil. Vol.16 No.1. ISSN: 2622-5549. Universitas Negeri Jakarta.

[6] Ardinal. R. Wirni. N. A. Haryati. 2020. "Pengaruh Penambahan Limbah Tongkol Jagung Untuk Pembuatan Batu Bata Ringan.” Jurnal Litbang Industri. Vol. 10 No. 1. ISSN: 2252-3367. Balai Riset dan Standarisasi Industri Padang.

[7] F. N. Abdi, R. Widayati, W. Ramadhani. 2018. "Pengaruh Penambahan Abu Tongkol Jagung Terhadap Kuat Tekan Beton Dengan Menggunakan Agregat Kasar Palu dan Agregat Halus Pasir Tenggarong", Jurnal Teknik Sipil. Vol. 3 No.1. ISSN: 2716-3520. Universitas Fajar Makassar. 
[8] I. R. Aditia. 2019 "Pengaruh Penambahan Abu Tongkol Jagung Sebagai Bahan Tambah Semen Terhadap Karakteristik Paving Block"

Jurnal Teknik Sipil. Edisi 1 Jilid 1. Universitas Mataram.

[9] SNI 1974:2011. “Cara Uji Kuat Tekan Beton Dengan Benda Uji Silinder”. Badan Standarisasi Nasional. Bandung.

[10] SNI 2491:2014. "Metode Pengujian Kuat Tarik Belah Spesimen Beton Silinder". Badan Standarisasi Nasional. Jakarta.

[11] E.G.Nawy. 1998. “Beton Bertulang Suatu Pendekatan Dasar”. Penerbit Refika Aditama.

[12] SNI 4431:2011. "Cara Uji Kuat Lentur Beton Dengan Dua Titik Pembebanan”. Badan Standarisasi Nasional. Bandung

[13] Adesanya. Raheem. 2009. "Development Of Corn Cob Ash Blended Cement,Construction And Building Materials”. Vol. 23. pp. 347-352”. 